\title{
Comparing the Effect of Wayang Pahlawan and Documentary Film for Cultivating Nationalism among Elementary School Student
}

\author{
Muhamad Taufik Hidayat", Ajib Rosyadi, Efi Rusdiyani, Afrin Puspasari \\ Elementary School Teacher Education, Universitas Muhammadiyah Surakarta, Surakarta, Indonesia
}

Received May 3, 2020; Revised May 26, 2020; Accepted July 7, 2020

Copyright $\mathrm{C} 2020$ by authors, all rights reserved. Authors agree that this article remains permanently open access under the terms of the Creative Commons Attribution License 4.0 International License

\begin{abstract}
The purpose of this study was to compare the effectiveness of Wayang Pahlawan (learning media) and documentary film (learning media) for cultivating nationalism among fourth-grade students. The type of this study was comparative with a quasi-experimental approach. This study was carried from March to July 2019. The subjects in this study were fourth-grade students (aged 9-10 years) at Public Elementary School of 9 Purwodadi, Central Java, Indonesia $(\mathrm{n}=38)$. Subjects were divided into two study groups. The first group was a group of students who received media treatment of Wayang Pahlawan. In contrast, the second group was a group of students who received media treatment of the documentary film. The data collection method used a questionnaire related to nationalism indicators. Validity test of items used the Product Moment Correlation, while KR 20 formula for reliability test. The normality test used the Liliefors method, the homogeneity test used the Leven test, while the hypothesis test used the Independent Sample T-Test. This study showed that Wayang Pahlawan and the documentary film showed an increase between the pretest and post-test results. It means that Wayang Pahlawan and documentary film can cultivate nationalism among fourth-grade students. Meanwhile, the documentary film was more effective in cultivating nationalism than Wayang Pahlawan. This study contributes to the existing literature about character education, especially nationalism. Data given will provide the elementary school teachers, department of elementary school teacher education, as well as ministry of education with information on how to cultivate nationalism effectively.
\end{abstract}

Keywords Learning Media, Documentary Film, Nationalism, Elementary School

\section{Introduction}

As an agent of reform, education is responsible for transferring and developing many positive values into the students' daily lives. Every student needs to be given various provisions such as ideology, life concepts, creativity, responsibility, and skills [1]. The efforts made in the context of fulfilling these demands are through the learning process.

In a learning process, there is an essential element, namely learning media. The use of learning media can arouse new desires and interests, generate motivation and stimulation, and bring psychological effects to students [2]. The use of learning media can help the effectiveness of the learning process and the delivery of learning content. In addition to arousing students' motivation and interest, learning media can also increase understanding, interest, and reliable data.

Many elementary schools in Indonesia show the less innovative in cultivating nationalism in the learning process. It is because Indonesian teachers in the learning process only focus on completing the material. Meanwhile, Indonesian teachers often let students find the noble character for themselves. Character building is essential to be implemented in schools because of its significant role and function as the center of civilization and development [3].

Therefore, the authors provide learning innovations through the Wayang Pahlawan (puppet heroes) learning media and documentary film learning media. These learning media made for students learning about the nationalism of heroes figures in maintaining independence. [4].

Wayang Pahlawan is a learning media that combines the art of puppets with Indonesian hero figures such as Soekarno (Indonesia's first President), Soedirman (Indonesian General), and Diponegoro (Indonesian Prince). 
The teacher appoints two students in the class to read the hero's history in the script and demonstrate the puppet. Through the Wayang Pahlawan show, students can pick various characters according to the hero figures presented. The use of puppets and scripts can involve and motivate students as well as improve their noble character [5].

A documentary film is a learning media contains a history or a character that has been played by an actor. A documentary film tells a fragment of a true story of an influential figure in the past or present [7]. The documentary films in this study about Soekarno, Soedirman, and Diponegoro. The teacher prepares a device such as a projector screen and speakers, then students watch and write about hero characters within the film.

The authors used the Wayang Pahlawan, and documentary film in the learning process using the Value Clarification Technique (VCT) learning model. The stages of the internalization technique consist of three: the value transformation stage, the value transaction stage, and the trans internalisation stage [8].

This study used a statistical hypothesis. The estimation of whether the sample data can be applied to the population is called a statistical hypothesis [9]. The statistical hypothesis that has tested in this study are as follows:

\section{Hypothesis 1}

$\mathrm{H}^{0} \quad$ : There is no difference between the average pretest and post-test results of students after applying the Wayang Pahlawan.

$\mathrm{H}^{1} \quad$ : There is a difference between the average pretest and post-test results of students after applying the Wayang Pahlawan.

\section{Hypothesis 2}

$\mathrm{H}^{0} \quad$ : There is no difference between the average pretest and post-test results of students after applying the documentary film.

$\mathrm{H}^{1} \quad$ : There is a difference between the average pretest and post-test results of students after applying the documentary film.

\section{Hypothesis 3}

$\mathrm{H}^{0} \quad$ : There is no difference between the average post-test results of students after applying the Wayang Pahlawan and documentary film.

$\mathrm{H}^{1} \quad$ : There is a difference between the average post-test results of students after applying the Wayang Pahlawan and documentary film.

\section{Materials and Methods}

This study was conducted at Public Elementary School of 9 Purwodadi, located at Grobogan, Central Java, Indonesia. This study was carried out from March to July
2019. The subjects in this study were fourth-grade students (aged 9-10 years) in the academic year 2018/2019 $(n=38)$. Subjects were divided into two study groups; each consists of 19 students.

This type of study is quantitative with a quasi-experimental design. The data analysis technique used was a comparative data analysis. Testing the comparative hypothesis means-testing population parameters in the form of differences [9].

This study used the quasi-experimental design because it did not allow us to control and manipulate all relevant variables fully. The dependent variable is nationalism (Y1), and the independent variable is learning media. Learning media variables were classified in the form of Wayang Pahlawan (X1) and documentary film (X2). Students, as a sample were grouped into two groups. The first group was a group of students who get media treatment of Wayang Pahlawan. In contrast, the second group was a group of students who get media treatment of the documentary film. Both groups had the same conditions before being given treatment.

The data collection technique in this study used a questionnaire. To find the validity of items of the instrument, the Product Moment Correlation by Pearson [10] was used. The reliability test in this study used the KR 20 formula by Kuder and Richardson [11].

In the data analysis stage, the normality test used the Liliefors method [12]. The homogeneity test used the Leven test [13]. The hypothesis test used the Independent Sample T-Test statistical test by Gosset [14].

Pictures of Wayang Pahlawan and documentary film can be seen in Figure 1:
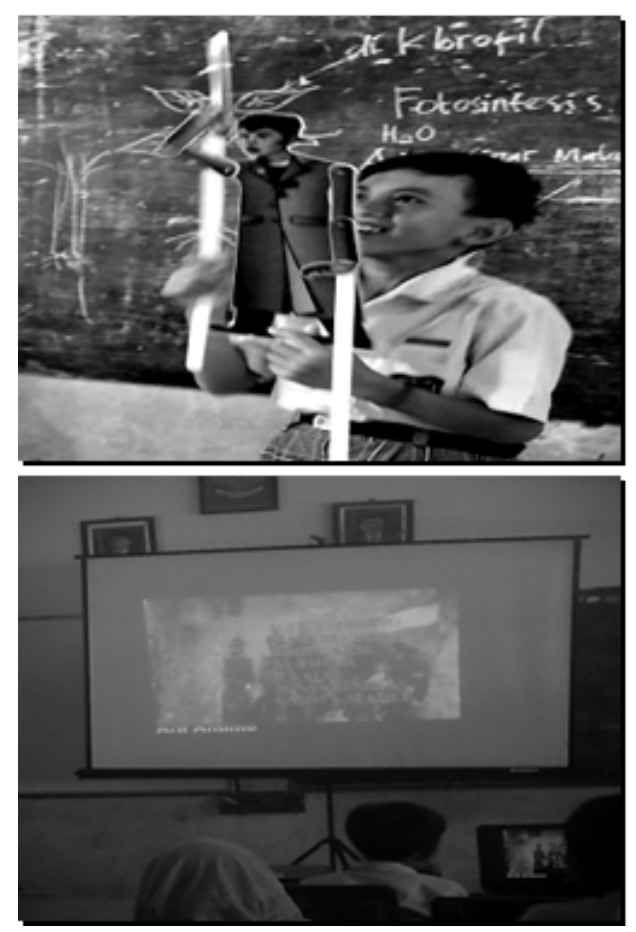

Figure 1. (Above) Demonstrating Wayang Pahlawan and (Below) Demonstrating Documentary Film 
Questionnaire grids were obtained from indicators of students' nationalism, which can be seen from their behavior. Table 1 shows attitudes or behaviors that reflect the nationalism [15] as follows:

Table 1. Questionnaire Indicators

\begin{tabular}{ccc}
\hline \multirow{2}{*}{ Indicator } & \multicolumn{2}{c}{ Item Number } \\
\cline { 2 - 3 } & Favorable & Unfavorable \\
\hline Proud to be Indonesian & 1,2 and 22 & 3 \\
\hline $\begin{array}{c}\text { Love the motherland and the } \\
\text { nation }\end{array}$ & 4 and 5 & 6 and 23 \\
\hline Willing to sacrifice for the nation & 7 & 8.9 and 24 \\
\hline Receiving plurality & 10 and 11 & 12 and 25 \\
\hline Proud of diverse cultures & 13 and 14 & 15 \\
\hline Appreciate the services of heroes & 16 and 17 & 18 \\
\hline Prioritizing the public interest & 19 and 21 & 20 \\
\hline Number of Items & & 25 \\
\hline
\end{tabular}

\section{Result}

\section{Test Validity of Instruments}

The validity test used to find item validity was Product Moment Correlation by Pearson [10] (See Table 2).

Table 2. Validity Test Result

\begin{tabular}{|c|c|c|c|}
\hline Item No & rxy & $\mathrm{R}(\mathbf{0 . 0 5} ; \mathbf{3 0})$ & Conclusion \\
\hline 1 & 0.136 & 0.349 & Invalid \\
\hline 2 & 0.498 & 0.349 & Valid \\
\hline 3 & 0.603 & 0.349 & Valid \\
\hline 4 & 0.412 & 0.349 & Valid \\
\hline 5 & 0.673 & 0.349 & Valid \\
\hline 6 & 0.643 & 0.349 & Valid \\
\hline 7 & 0.138 & 0.349 & Invalid \\
\hline 8 & 0.734 & 0.349 & Valid \\
\hline 9 & 0.597 & 0.349 & Valid \\
\hline 10 & 0.423 & 0.349 & Valid \\
\hline 11 & 0750 & 0.349 & Valid \\
\hline 12 & 0.271 & 0.349 & Invalid \\
\hline 13 & 0.369 & 0.349 & Valid \\
\hline 14 & 0.398 & 0.349 & Valid \\
\hline 15 & 0.317 & 0.349 & Invalid \\
\hline 16 & 0.398 & 0.349 & Valid \\
\hline 17 & 0.392 & 0.349 & Valid \\
\hline 18 & 0.408 & 0.349 & Valid \\
\hline 19 & 0.483 & 0.349 & Valid \\
\hline 20 & 0.478 & 0.349 & Valid \\
\hline 21 & 0.532 & 0.349 & Valid \\
\hline 22 & 0.369 & 0.349 & Valid \\
\hline 23 & 0.303 & 0.349 & Invalid \\
\hline 24 & 0.704 & 0.349 & Valid \\
\hline 25 & 0.494 & 0.349 & Valid \\
\hline
\end{tabular}

\section{Reliability Test}

The reliability test in this study used was the KR 20 formula by Kuder and Richardson [11] (See Table 3).

Table 3. Reliability Test Results

\begin{tabular}{cccc}
\hline Variable & $\mathbf{r}_{11}$ & $\mathbf{r}_{(0,05 ; 30)}$ & Note \\
\hline Nationalism & 0.664 & 0.349 & Reliable \\
\hline
\end{tabular}

\section{Normality Test}

The normality test was used to determine whether the study sample is from a normal population or not. The normality test used was the Liliefors method [12] (See Table 4).

Table 4. Normality Test Result

\begin{tabular}{ccccc}
\hline Variable & Group & Lcount & Ltable & Note \\
\hline \multirow{2}{*}{ Nationalim } & Experiment I & 0.21424 & 0.195 & Normal \\
\cline { 2 - 5 } & Experiment II & 0.22202 & 0.195 & Normal \\
\hline
\end{tabular}

\section{Homogeneity Test}

The homogeneity test aims to determine whether the two groups have the same variance or not. If both groups have the same variance, the group is homogeneous. To test the homogeneity, the Levene test [13] was used (See Table 5).

Table 5. Homogeneity Test Results

\begin{tabular}{cccc}
\hline Source of Variation & Sig. & $\alpha$ & Note \\
\hline Nationalism & 0.284 & 0.05 & Homogeneous \\
\hline
\end{tabular}

\section{Hypothesis Testing}

In knowing how big the difference is in learning using the VCT model with Wayang Pahlawan and documentary film to cultivate nationalism, the authors used the Independent Sample T-Test statistical test by Gosset [14]. Showing the following results:

\section{First Hypothesis}

Table 6. First Hypothesis Test Result

\begin{tabular}{cccc}
\hline Nationalism & mean & Tcount & Ttable \\
\cline { 1 - 2 } Pretest & 69.74 & & \\
\cline { 1 - 2 } Posttest & 72.29 & & 1.688 \\
\hline
\end{tabular}

Based on Table 6, it can be seen the result of Tcount $=$ $-4.152<$ Ttable $=1.688$. Ho was rejected, and H1 was accepted. There was a difference between the pretest and posttest results of students after applying the Wayang Pahlawan. 


\section{Second Hypothesis}

Table 7. Second Hypothesis Test Result

\begin{tabular}{cccc}
\hline Nationalism & mean & Tcount & Ttable \\
\hline Pretest & 71.31 & & \\
\cline { 1 - 2 } Posttest & 75.26 & & 1.683 \\
\hline
\end{tabular}

Based on Table 7, it can be seen the result of Tcount $=$ $-3.633<$ Ttable $=1.688$. Ho was rejected, and $\mathrm{H} 1$ was accepted. There was a difference between the pretest and posttest results of students after applying the documentary film.

\section{Third Hypothesis}

Table 8. Third Hypothesis Test Result

\begin{tabular}{cccc}
\hline Nationalism & mean & Tcount & Ttable \\
\hline Wayang Pahlawan & 72.78 & & \\
\cline { 1 - 2 } Documentary Film & 75.26 & & 1.529 \\
\hline
\end{tabular}

Table 8 shows the result of Tcount $=-1.529<$ Ttable $=$ 1.688. Ho was rejected, and H1 was accepted. There was a difference between the average posttest results of students after applying the Wayang Pahlawan and documentary film.

\section{Discussion}

\section{The Effect of Wayang Pahlawan}

Based on the result of the study, there was an increase in nationalism after applying Wayang Pahlawan in the learning activity. This finding shows similarity with the study by Nurgiyantoro [16] that Wayang story presents a good role model that deserves to be imitated. Another study by Nurasiah, Uswatun, \& Amalia [17] found that Sukuraga Wayang can be used as a character education media.

The unique forms of wayang facilitate the transfer of knowledge as well as a noble character. Students easily remember the wayang characters as well as meaningful narratives. Students also easily imitate and apply the noble character in their lives. Not only cognitive abilities but also affective and psychomotor abilities of students would be improved.

This statement is in line with Klein-Ezell, Ezell, Stanley, \& Powell [5] that teaching of a noble character using children's literature, puppets, magic tricks, and balloon are fun and impressive ways to illustrate the critical points of character education. Using a combination of these methods increases the possibility of students to remember the noble characters.

The application of Wayang Pahlawan is indicated to make a learning activity more exciting and conducive for students. On the other hand, the learning activity can improve the nationalism of the students themselves.
Teacher's innovation in learning is crucial in cultivating character, especially nationalism. Change in the use of learning models and learning media aims to make students feel enthusiastic in the learning activity.

This finding is in line with the study by Korošec [18], who found that puppets are instruments that are linked to the curriculum and motivate children to be enthusiastic. Moreover, learning with puppets with carefully planned and based on curriculum allows improvisation by the teacher.

Using wayang was also Indicated able to increase students' vocabulary, as seen from the wayang show. In a wayang show, the audience must be able to understand the story witnessed. After following the story, the audience can get some new words. Wijayanti \& Sulaksono [19] found that the application of wayang through project-based learning can improve the students' ability to use Javanese vocabulary as expected.

\section{The Effect of Documentary Film}

Based on the result of the study, there was an increase in nationalism after applying some documentary films in the learning activity. This study shows the similarity finding with the study of Russel \& Waters [20] that teaching using film (to stimulate discussion of moral dilemmas) gives students unique and exciting opportunities for intellectual and moral growth.

Using documentary film can also improve students' learning outcomes because students can correctly understand the storyline presented on film. This finding strengthens finding by Suharyanto [21] that the application of the VCT model and documentary film is very effective. It can be seen from teachers' observations, students' attitudes, analysis of student worksheets, and students' responses. The result of the attitude scale test showing the VCT model assisted by the documentary film is effective in cultivating nationalism.

The application of documentary film is indicated to make learning attractive, conducive, and improving the nationalism of students. Through the use of documentary film, we can improve the quality of education. This statement is in line with definition by Asyhar [22] that audio-visual media is a type of media used in learning activities by involving hearing and vision in one activity. Messages and information that can be transferred through this media can be verbal and nonverbal, which relies on both vision and hearing.

\section{Conclusions}

Based on the results, it can be concluded that: (1) VCT learning model with Wayang Pahlawan effectively cultivate the nationalism of fourth-grade elementary school students. (2) VCT learning model with the documentary 
film is effective to cultivate nationalism of fourth grade elementary school students. (3) VCT learning model with the documentary film is more effective than the VCT learning model with Wayang Pahlawan to cultivate nationalism of fourth-grade elementary school students.

The results of the present study would be beneficial to the following: (1) Elementary School Teachers. Data given will provide the elementary school teachers with information on how to cultivate nationalism effectively. The results will enable elementary school teachers to improve the character learning, especially in Civics material. (2) Department of Elementary School Teacher Education. The present study results will help the lecturers evaluate the quality of learning by students; with the character learning. (3) Ministry of Education. The present study will improve the ministry of education in the development of character education. This present study will foster new techniques (with various types of puppets) to enhance nationalism in the future. Each country, even each area of the country, likely has its unique puppets to be developed. This study will also help in the advancement of the Civics learning and teaching-evaluation approach.

\section{Acknowledgments}

In this study, I would like to thank Mrs. Risminawati, principal, teachers, and students of Public Elementary School 9 Purwodadi.

\section{REFERENCES}

[1] Amir, S. (2013). Pancasila As Integration Philosophy of Education and National Character. International Journal Of Scientific \& Technology Research, Vol. 2, Issue 1 hh. 54-57. http://www.ijstr.org/final-print/jan2013/Pancasila-As-Integr ation-Philosophy-Of-Education-And-National-Character.pd $\mathrm{f}$

[2] Izzaty, R. E. (2013). Perkembangan Peserta Didik [Student Development]. Yogyakarta: UNY Press.

[3] Supriatna, E. (2017). Study on the Best Practice of Character Building with Value Clarification Technique Approach at the Integrated Islamic Elementary Schools. TAWARIKH (International Journal for Historical Studies), Vol. 9, Issue 1, hh.95-114.

https://mindamas-journals.com/tawarikh/article/download/8 97/822.pdf

[4] Azmi, S., Ardhana, W., Degeng, S., \& Kamdi, W. (2017). The Effect of Value Clarification Learning Strategy (Group Interview Type and Consequences Search Type) on Respect for Diversities of Students Who Have Different Cognitive Styles in the Civic Education. The International Journal Of Science \& Technoledge, Vol. 5, Issue 5, hh. 71-78. $\mathrm{http}$ ://internationaljournalcorner.com/index.php/theijst/artic le/view/123546/84687
[5] Klein-Ezell, C., Ezell, D., Stanley, P., \& Powell, E. (2014), Character Education Using Children's Literature, Puppets, Magic Tricks and Balloon Art. International Journal of Humanities and Social Science, Vol.4, No.14,nhh.1-15. http://www.ijhssnet.com/journals/Vol_4_No_14_December 2014/1.pdf

[6] Kröger, T., \& Nupponen, M. (2019). Puppet as a Pedagogical Tool: A Literature Review. IEJEE (International Electronic Journal Of Elementary Education), Volume 11, Issue 4 ISSN: 1307-9298, hh. 393-401. https://files.eric.ed.gov/fulltext/EJ1212334.pdf

[7] Hudoyo, S., \& Mulia, B. (2014). Representasi Keluarga Jawa dalam Film Jokowi [Representation of Javanese Family in Jokowi's Film]. CAPTURE (Jurnal Seni Media Rekam), Vol.6,No.1,hh.90-105. https://jurnal.isi-ska.ac.id/in dex.php/capture/article/view/729/729

[8] Shodiq, F. (2017). Pendidikan Karakter Melalui Pendekatan Penanaman Nilai dan Pendekatan Perkembangan Moral Kognitif [Character Education Through the Value Investment Approach and Cognitive Moral Development Approach]. At-Tajdid, Vol. 1, No. 1, hh.14-25.

[9] https://ojs.ummetro.ac.id/index.php/attajdid/article/downloa $\mathrm{d} / 332 / 266$

[10] Sugiyono. (2015). Metode Penelitian Pendidikan [Educational Research Methods]. Bandung: Alfabeta.

[11] Pearson, Karl. (1948). Early Statistical Papers. Cambridge, England: University Press

[12] Kuder, G.F., Richardson, M.W. (1937). The theory of the estimation of test reliability. Psychometrika 2, 151-160 https://doi.org/10.1007/BF02288391

[13] Lilliefors, Hubert W. (1967). On the Kolmogorov-Smirnov Test for Normality with Mean and Variance Unknown, Journal of the American Statistical Association, 62:318, 399-402, DOI: 10.1080/01621459.1967.10482916

[14] Levene, H.,. (1960). "Robust Tests for Equality of Variances," in I. Olkin, ed., Contributions to Probability and Statistics, Palo Alto,. California: Stanford University Press

[15] Gosset, William Sealy (1908). "The probable error of a mean" (PDF). Biometrika. 6 (1): 1-25. doi:10.1093/biomet/ 6.1 .1

[16] Kementerian Pendidikan dan Kebudayaan, (2016). Konsep dan Penguatan Pendidikan Karakter Tingkat Sekolah Dasar dan Sekolah Menengah Pertama [Concept and Strengthening of Elementary and Middle School Level Character Education]

[17] Nurgiyantoro, B. (2011). Wayang dan Pengembangan Karakter Bangsa. Wayang telah diakui UNESCO sebagai Masterpiece of Oral and Intangible Heritage of Humanity [Puppet and Nation Character Development. Puppet has been recognized by UNESCO as the Masterpiece of Oral and Intangible Heritage of Humanity] Jurnal Pendidikan Karakter, Tahun I, No. 1, hh. 18-34. https://journal.uny.ac.i d/index.php/jpka/article/view/1314/1092

[18] Nurasiah, I., Uswatun, D. A., \& Amalia, A. R. (2017). Building Character And Literacy Skills Of Primary School Students Through Puppet Contemplative Sukuraga. Vidyottama Sanatana: International Journal of Hindu 
Science and Religious Studies, 1(1), 40-45. https://ejournal.ihdn.ac.id/index.php/IJHSRS/article/view/1 $52 / 135$

[19] Korošec, H. (2012). Playing with puppets in class-teaching and learning with pleasure. The Power of the Puppet, 29 -45. https://www.unima.org/uploads/media/The_Power_of the Puppet_Eng_edited_02.pdf

[20] Wijayanti, K. D., \& Sulaksono, D. (2019, February). Character Building for Early Childhood Learners Through the Shadow Puppet-Based Javanese Language Manners. In Third International Conference of Arts, Language and Culture (ICALC 2018). Atlantis Press. https://download.atlantis-press.com/proceedings/icalc-18/5 5913486

[21] Russell III, W. B., \& Waters, S. (2013). "Reel" Character
Education: Using Film to Promote Global Citizenship. Childhood Education, 89 (5), 303-309. https://www.tandfonline.com/doi/abs/10.1080/00094056.20 13.830901

[22] Sutaryanto. (2015). Penerapan Model Value Clarification Technique (VCT) Berbantuan Film Dokumenter dalam Menanamkan Nilai Nasionalisme dan Meningkatkan Hasil Belajar pada Siswa Sekolah Dasar [Application of the Model Value Clarification Technique (VCT) Assisted by Documentary Films in Instilling Nationalism Values and Improving Learning Outcomes in Elementary School Students]. Primere Educandum, Vol. 5,No.2,hh.237-252. http://e-journal.unipma.ac.id/index.php/PE/article/view/287

[23] Asyhar, R. (2011). Kreatif Mengembangkan Media Pembelajaran [Creative Developing Learning Media]. Jakarta: Gaung Persada 